\title{
Allelopathy of the Leaf Extract of Eucalyptus Genetic Material on the Physiological Performance of Millet Seeds
}

\author{
Marcos Vinicius de Sousa ${ }^{1}$, Séfora Gil Gomes de Farias ${ }^{1 *}$, Déborah Praciano de Castro², \\ Romário Bezerra e Silva1, Dandara Yasmim Bonfim de Oliveira Silva1', Bruna Anair Souto Dias ${ }^{1}$, \\ Alexandre Faria da Silva ${ }^{1}$, Graziele Nunes Lopes dos Santos ${ }^{1}$, Daniele Cristina Pereira de Matos ${ }^{1}$, \\ Caio Varonill de Almada Oliveira ${ }^{3}$
}

\author{
${ }^{1}$ Universidade Federal do Piauí (UFPI), Bom Jesus, Brazil \\ ${ }^{2}$ Universidade Estadual do Ceará, UECE, Fortaleza, Brazil \\ ${ }^{3}$ Universidade Federal de Viçosa, Viçosa, Brazil \\ Email:markin.hos.25@hotmail.com, *seflora@gmail.com,deborahpraciano@gmail.com,romariobs@gmail.com, \\ dandara.yasmim@hotmail.com,brunasoutodias@gmail.com, afsilva9@hotmail.com,grazielenunes95@hotmail.com, \\ danieleCristina94@hotmail.com,caiovaronill@gmail.com
}

How to cite this paper: Sousa, M.V., Farias, S.G.G., Castro, D.P., Silva, R.B., Silva, D.Y.B.O., Dias, B.A.S., Silva, A.F., Santos, G.N.L., Matos, D.C.P. and Oliveira, C.V.A. (2018) Allelopathy of the Leaf Extract of Eucalyptus Genetic Material on the Physiological Performance of Millet Seeds. American Journal of Plant Sciences, 9, 34-45. https://doi.org/10.4236/ajps.2018.91004

Received: November 24, 2017

Accepted: January 8, 2018

Published: January 11, 2018

Copyright $\odot 2018$ by authors and Scientific Research Publishing Inc. This work is licensed under the Creative Commons Attribution International License (CC BY 4.0).

http://creativecommons.org/licenses/by/4.0/ (c) (i) Open Access

\begin{abstract}
This study aims to evaluate the possible allelopathic effects of young and mature leaf extract from of two eucalyptus genetic materials on the physiological performance of millet seeds. The experiment was carried out in a completely randomized design, in a $5 \times 2 \times 2$ factorial arrangement [five concentrations of the extract $(0,25 \%, 50 \%, 75 \%$, and $100 \%) \times$ two genetic materials $(1-E u$ calyptus grandis $\times$ Eucalyptus urophylla and $2-$ Eucalyptus grandis $\times$ Eucalyptus camaldulensis) $\times$ two maturation stages of leaves (young and mature leaves)] with four replicates, each one with 25 seeds. Seeding was performed on the germitest paper substrate distributed in Petri dishes, moistened with the extract according to the treatments, being allocated in biochemical oxygen demand (B.O.D) adjusted at $25^{\circ} \mathrm{C}$ and $12 \mathrm{~h}$ photoperiod. Percentage, speed index, mean germination time, aerial part and primary root length, and dry matter weight of aerial part and root system of seedlings were evaluated. The leaf extracts of the two eucalyptus clones had all the analyzed variables changed with effect more evident on young leaf extract of the genetic material 1. It can be concluded that the tested genetic materials have a detrimental effect on the physiological performance of millet seeds.
\end{abstract}

\section{Keywords}

Allelopathic, Germination, Pennisetum glaucum, Seedlings, Germination Speed 


\section{Introduction}

Allelopathy is known as mechanism of chemical interaction among plants that plays important roles in the ecosystem [1]. Effects of this mechanism can be verified on all organisms; however, its manifestation becomes more evident in plants [2], influencing plant dominance, succession, formation of plant communities, and climax vegetation, just as productivity and crop management [3].

Among the allelopathic compounds, short chain acids, essential oils, phenolic compounds, alkaloids, steroids, terpenes, unsaturated lactones, and coumarin derivatives are highlighted and can be released in many ways in the air, excreted by the root, or carried to the ground by rainwater [4], which may interfere with the growth and vigor of plants, and inhibit seed germination of many species [2].

In recent years, many efforts have been made to combine production, conservation, and preservation; in this context, integration systems of agricultural, forestry, and pastoral activities stand out as a viable alternative. There are many tree species that present the potential or composing systems of crop-livestock-forest integration (CLFI) and silvipastoral systems (tree + pasture/animal) (SPSs). In Brazil, eucalyptus mainly has been distinguished with large numbers of species and many interspecific hybrids, enabling to select the most suitable genetic material, according to each purpose and climatic and soils conditions.

Eucalyptus genus has some species considered potentially allelopathic. It can also be used as important component of CLFI and SPS systems [5]. Thus, it is important to gather efforts to identify allelopathic properties in species with potential to compose the CLFI and SPS systems such as eucalyptus, since there is considerable number of species and hybrids with such useful potential for these systems.

Millet (Pennisetum glaucum) is looked like an alternative of straw production for soil cover in no-tillage areas, due to its drought-resistant agronomic characteristics, wide adaptation, and good mass production, combined with fast growth, low deployment cost, and good nutritional quality [6]. It is also widely cultivated in a consortium with leguminous vegetables, with great importance in Brazil, particularly in the cerrado (Brazilian savannah) region, and it is an excellent alternative for integrating systems.

Effects of aqueous extracts and essential oils on seed germination and initial seedling growth have been shown for some species, such as Eucalyptus globulus L. and Eucalyptus grandis [5] [7]; Achillea millefolium L. [8]; Corymbia citriodora (Hook.) K. D. Hill \& L. A. S. Johnson [9]; Baccharis dracunculifolia [10], among others; however, there is no information for the genetic materials of $E u$ calyptus grandis $\times$ Eucalyptus urophylla and Eucalyptus grandis $\times$ Eucalyptus camaldulensis. These genetic materials are among the most commercially cultivated in the State of Piauí, Brazil.

Considering the importance that many species and hybrids of eucalyptus represent for restoration, preservation, supply of raw material, and mainly as potential for the CLFI and SPSs systems, together with the information lack re- 
garding the allelopathy process, this work was carried out with the objective to evaluate the allelopathic potential of young and mature leaves extract from two eucalyptus genetic materials [(1) Eucalyptus grandis $\times$ Eucalyptus urophylla; and (2) Eucalyptus grandis $\times$ Eucalyptus camaldulensis] on the physiological performance of millet (Pennisetum glaucum) seeds.

\section{Material and Methods}

This experiment was carried out at the Ecophysiology Laboratory of the Federal University of Piauí (UFPI), Professora Cinobelina Elvas Campus (CPCE) in Bom Jesus municipality, Piauí State (PI), Brazil.

The experimental design was completely randomized, in $5 \times 2 \times 2$ factorial arrangement (five concentrations of the extract $(0,25 \%, 50 \%, 75 \%$, and $100 \%) \times$ two genetic materials (clones) [(1) Eucalyptus grandis $\times$ Eucalyptus urophylla; and (2) Eucalyptus grandis $\times$ Eucalyptus camaldulensis $] \times$ two maturation stages of leaves (young and mature leaves).

Leaf collection was carried out in four clonal trees of Eucalyptus grandis $\times$ Eucalyptus urophylla (EC 02) and Eucalyptus grandis $\times$ Eucalyptus camaldulensis (EC 01) hybrids, in different positions of the canopy, aiming to separate young leaves (collected in the apical regions) and mature leaves (collected at the canopy base).

The trees of the two clones above mentioned are part of a clonal test, implemented in March 2014, in a multiclonal scheme with $3 \mathrm{~m} \times 2 \mathrm{~m}$ spacing (three meters among rows and two meters among plants), so that each planting line contains a genetic material, being 35 plants per clone. The clonal test is located at Escola Alvorada Farm, belonging to the Federal University of Piauí (UFPI), Professora Cinobelina Elvas Campus (CPCE), located in the municipality of Alvorada do Gurguéia, southwest region of the State of Piauí, Brazil.

In the preparation, the extracts were considered at $10 \mathrm{~g}$ ratio vegetal material to $200 \mathrm{~mL}$ distilled water, milled in blender at the maximum speed (3) for approximately two minutes, producing the crude aqueous extract (100\%). Dilutions with distilled water were made from the crude extract (100\%), producing $25 \%, 50 \%$, and $75 \%$ extract concentrations and distilled water was used as control treatment.

After preparing the extract, a sample of the crude extract (100\%) was taken for $\mathrm{pH}$ measurement. Only the crude extract was measured, since, in accordance with [2], the dilutions of the extracts carried out in distilled water do not affect the change of $\mathrm{pH}$ values. Millet seeds (ADR-300 cultivar) were obtained commercially in the city of Bom Jesus, Piauí State, Brazil.

The germination test was carried out on $90 \times 15 \mathrm{~mm}$ sterilized petri dishes, and sowing was performed between the germitest substrate, moistened with the extracts according to the treatments in the amount of 2.5 times the dry paper weight [11]. After sowing, the Petri dishes were kept in a germinating Biochemical Oxygen Demand (B.O.D) type chamber, regulated at $25^{\circ} \mathrm{C}$ constant temper- 
ature and 12 hours photoperiod for seven days. For each treatment, four replicates were used and each replicate containing 25 seeds.

The germination count was made daily, with radicle emission $(2 \mathrm{~mm}$ radicular protrusion) as germination criterion.

The following variables were evaluated: 1) germination (G\%) - the germination percentage corresponded to the total number of seeds germinated in the last evaluation (seven days after sowing); 2) germination speed index (GSI) was performed together with the germination test, and the germinated seed count was performed daily at the same time from the first count until the value became constant. GSI was obtained using the formula proposed by [12], which is presented following: GSI $=G_{1} / N_{1}+G_{2} / N_{2}+\cdots+G_{n} / N_{n}$, where: $G_{1}, G_{2}, \cdots G_{n}=$ number of germinated seeds in each day and $N_{1}, N_{2}, \cdots N_{n}$ = number of days elapsed since the day of sowing; 3 ) length of the primary root and aerial part-at the end of the experiment, using a graduated ruler, the length of the primary root and of the aerial part of the normal seedlings of each replicate was measured. The mean length was obtained with the sum of the measurements of each part of the seedling (root and aerial part) of each replicate, divided by the number of measured normal seedlings; results were expressed in cm plântula ${ }^{-1}$ [13]; and 4) dry mass of the root system and aerial part-the normal seedlings previously measured in each replicate were conditioned in Kraft paper bags, previously identified, weighed, and taken to the forced ventilation oven, regulated at $80^{\circ} \mathrm{C}$, for 24 hours. After this period, the samples were removed from the greenhouse and weighed using analytical balance with $0.001 \mathrm{~g}$ accuracy, and the mean results were expressed in $\mathrm{mg}_{\text {plântula }}{ }^{-1}$ [13].

Data were submitted to the normality test (Lilliefors) and to the homogeneity of variances (Cochran) to verify the need for data transformation and, afterwards, submitted to analysis of variance (ANOVA); when significant effect of the treatments was verified, the means were compared by the Scott-Knott test at $5 \%$ probability. Statistical analyzes were made using the SISVAR (DEX/UFLA) software, version 5.6 [14].

\section{Results and Discussion}

It is known that medium with extremely acidic or alkaline $\mathrm{pH}$ can affect germination performance and seedling growth, observed generally under conditions of $\mathrm{pH}$ below 4 and above 10 [15]. Therefore, the $\mathrm{pH}$ determination of the extracts used for the determination of allelopathic effects is fundamental when its constitution in organic acids and other molecules is not known, because extreme $\mathrm{pH}$ values of the extracts can act on the seeds and/or seedlings, and mask the allelopathic effect [5].

The $\mathrm{pH}$ values of the crude aqueous extracts $(100 \%)$ of young and mature leaves of E. grandis $\times$ E. urophylla and E. grandis $\times$ E. camaldulensis were 5.45 and 5.55; and 5.29 and 5.22, respectively. Thus, the $\mathrm{pH}$ of the extracts used in this study was found within an acceptable values range, so, non-interfering on 
seed germinability and seedling growth.

The analysis of variance of the interaction among the tested factors was significant for all analyzed variables ( $\mathrm{p} \leq 0.05)$.

Regardless of the genetic material and the maturation stage of the leaves, significant reduction in the germination percentage and in the Germination Speed Index (GSI) was observed, considering 25\% extract concentration (Table 1). This result may be related to the effect of allelochemicals released by the leaves of the genetic materials of the eucalyptus used in this study. Reports indicate that the Eucalyptus genus has many species with allelopathic potential [5].

Table 1. Average values of germination (\%) and Germination Speed Index (GSI) (\%) of millet seeds submitted to the action of different concentrations of young and mature leaf extracts from different genetic materials of eucalyptus.

\begin{tabular}{|c|c|c|c|c|}
\hline \multicolumn{5}{|c|}{ Germination } \\
\hline \multicolumn{5}{|c|}{ Genetic Material } \\
\hline \multirow{3}{*}{$\begin{array}{l}\text { Extract Concentra- } \\
\text { tions }\end{array}$} & \multicolumn{2}{|c|}{ E. grandis $\times$ E. urophylla } & \multicolumn{2}{|c|}{ E. grandis $\times$ E. camaldulensis } \\
\hline & \multicolumn{4}{|c|}{ Leaf } \\
\hline & Young & Mature & Young & Mature \\
\hline $0 \%$ & $84 \mathrm{Aa} \alpha$ & $84 \mathrm{Aa} \alpha$ & $84 \mathrm{Aa} \alpha$ & $84 \mathrm{Aa} \alpha$ \\
\hline $25 \%$ & $56 \mathrm{Ca} \beta$ & $71 \mathrm{Ba} \alpha$ & $64 \mathrm{Ba} \alpha$ & $72 \mathrm{Ba} \alpha$ \\
\hline $50 \%$ & $73 \mathrm{Ba} \alpha$ & $60 \mathrm{Ca} \beta$ & $54 \mathrm{Cb} \beta$ & $66 \mathrm{Ba} \alpha$ \\
\hline $75 \%$ & $43 \mathrm{Db} \beta$ & $71 \mathrm{Ba} \alpha$ & $52 \mathrm{Ca} \alpha$ & $45 \mathrm{Cb} \alpha$ \\
\hline $100 \%$ & $56 \mathrm{Ca} \beta$ & $70 \mathrm{Ba} \alpha$ & $47 \mathrm{Cb} \alpha$ & $50 \mathrm{Cb} \alpha$ \\
\hline \multicolumn{5}{|c|}{ GSI } \\
\hline \multicolumn{5}{|c|}{ Genetic Material } \\
\hline \multirow{3}{*}{$\begin{array}{c}\text { Extract Concentra- } \\
\text { tions }\end{array}$} & E. grand & Irophylla & E. grandis & aldulensis \\
\hline & \multicolumn{4}{|c|}{ Leaf } \\
\hline & Young & Mature & Young & Mature \\
\hline $0 \%$ & $8.74 \mathrm{Aa} \alpha$ & 8.74 $\mathrm{Aa} \alpha$ & $8.74 \mathrm{Aa} \alpha$ & $8.74 \mathrm{Aa} \alpha$ \\
\hline $25 \%$ & $5.32 \mathrm{Ca} \beta$ & $6.67 \mathrm{Ba} \alpha$ & $6.21 \mathrm{Ba} \alpha$ & $6.36 \mathrm{Ba} \alpha$ \\
\hline $50 \%$ & $7.52 \mathrm{Ba} \alpha$ & $4.92 \mathrm{Cb} \beta$ & $5.18 \mathrm{Cb} \alpha$ & $6.13 \mathrm{Ba} \alpha$ \\
\hline $75 \%$ & $3.79 \mathrm{Da} \beta$ & $5.93 \mathrm{Ba} \alpha$ & $4.01 \mathrm{Da} \alpha$ & $3.99 \mathrm{Cb} \alpha$ \\
\hline \multirow[t]{3}{*}{$100 \%$} & $5.20 \mathrm{Ca} \alpha$ & $5.71 \mathrm{Ba} \alpha$ & $3.82 \mathrm{Da} \alpha$ & $4.18 \mathrm{Cb} \alpha$ \\
\hline & \multicolumn{3}{|c|}{ F Values } & \\
\hline & \multicolumn{2}{|c|}{ Germination } & \multicolumn{2}{|c|}{ GSI } \\
\hline GM & \multicolumn{2}{|c|}{$14.591^{* *}$} & \multicolumn{2}{|c|}{$11.833^{\star *}$} \\
\hline LMS & \multicolumn{2}{|c|}{$21.012^{* *}$} & \multicolumn{2}{|c|}{$3.589^{\mathrm{ns}}$} \\
\hline EC & \multicolumn{2}{|c|}{$69.782^{* *}$} & \multicolumn{2}{|c|}{$102.785^{\star \star}$} \\
\hline $\begin{array}{c}\text { Interaction } \\
(\mathrm{GM} \times \mathrm{LMS} \times \mathrm{EC})\end{array}$ & \multicolumn{2}{|c|}{$13.593^{* *}$} & \multicolumn{2}{|c|}{$10.287^{\star *}$} \\
\hline CV (\%) & \multicolumn{2}{|c|}{9.10} & \multicolumn{2}{|c|}{11.22} \\
\hline
\end{tabular}

Means followed by the same capital letter in the column [extract concentrations (EC)], lowercase in the line (different genetic material (GM) and the same leaf maturation stage (LMS)) and means followed by the same Greek letter in the line [different Leaf Maturation Stages (LMS)] and the same genetic material) do not differ from each other by the Scott-Knott test at $5 \%$ level. ${ }^{*}$ Significant at $1 \%$ of probability by the $\mathrm{F}$ test, ${ }^{*}$ Significant at $5 \%$ of probability by the $\mathrm{F}$ test and ${ }^{\mathrm{ns}}$ Not significant. 
[1] evaluating the allelopathic effect of aqueous extracts of Eucalyptus globulusLabill. and Casearia sylvestris Sw., on germination and initial growth of mustard (Brassica campestris L.), cabbage (Brassica oleracea L. capitata), broccoli (Brassica oleracea L. cv. Italica), cole - Chinese cabbage - (Brassica pekinensis L.) lettuce (Lactuca sativa L. cv. grand rapids), tomato (Lycopersicum esculentum Miller), turnip (Brassica rapa L.), arugula (Eruca sativa L.), and radish (Raphanus sativus $\mathrm{L}$.) found that these species are potentially allelopathic for reducing and/or inhibiting germination, GSI, and initial growth of the root system and aerial part, and the eucalyptus is the species with the greatest inhibitory potentialities on the tested vegetables.

In most cases, the allelopathic effect is more evident when leaf extracts are used [9] [16]. [17], evaluating the allelopathic potential of the aqueous extract of leaves of Corymbia citriodora (Hook.) K. D. Hill \& L. A. S, verified that the onion culture had its percentage and germination speed reduced with the increase of the extract concentrations $(0,20 \%, 40 \%, 60 \%, 80 \%$, and $100 \%)$ in the germination medium.

In another work, [7] evaluated the concentration effect of $0,25,50,75$, and $100 \%$ aqueous extract of Eucalyptus grandis leaves on germination of lettuce seeds (Lactuca sativa L.) and carioca beans (beans with khaki stripes on a beige background) (Phaseolus vulgaris L.), and they found germination inhibition from $50 \%$ extract concentration for lettuce seeds, but the bean seeds germination was not affected, suggesting that the allelochemicals effect depends on the target species and that some of them are more sensitive than others. [9] pointed out that in addition to the studied species, these effects may also vary according to the preparation way, application form, concentration, and exposure time of the seeds to the extract.

The tested leaf extracts also influenced the initial growth of millet seedlings when compared to control treatment. When the average values of seedling length were verified, it was observed that the primary root length was more sensitive to the increase of the extract concentrations than the aerial part. When analyzing the mean values of the primary root length of millet seedlings, decrease from $25 \%$ concentration was observed for most of the evaluated treatments, independently of the leaves maturation stage (Table 2). For this variable, it is verified that the $E$. grandis $\times E$. camaldulensis genetic material affected negatively the primary root length.

Similarly to study, [18] when studying the allelopathic effect of Eucalyptus urograndis by testing aqueous concentrations of leaves $(0,12.5 \%, 25 \%, 50 \%$, and $100 \%)$ on germination and initial seedling growth of Urochloa decumbens and Panicum maximum, found that the germination speed index and primary root length were the parameters most affected by the potentially allelopathic substances present in leaf extracts. [10], studying the allelopathy of Joanesia princeps $\mathrm{V}$ ell. and Casearia sylvestris $\mathrm{Sw}$. on cultivated species, also verified that the primary root was the plant structure most affected by the used extracts. 
Table 2. Mean values of the main root length (RL) and aerial part length (APL) of seedlings $\left(\mathrm{cm}\right.$ plantula ${ }^{-1}$ ) of millet submitted to the action of extract different concentrations of young and mature leaves of different genetic materials of eucalyptus.

RL

\begin{tabular}{|c|c|c|c|c|}
\hline \multicolumn{5}{|c|}{ Genetic Material } \\
\hline \multirow{3}{*}{$\begin{array}{c}\text { Extract } \\
\text { Concentrations }\end{array}$} & \multicolumn{2}{|c|}{ E. grandis $\times$ E. urophylla } & \multicolumn{2}{|c|}{ E. grandis $\times$ E. camaldulensis } \\
\hline & \multicolumn{4}{|c|}{ Leaf } \\
\hline & Young & Mature & Young & Mature \\
\hline $0 \%$ & $3.55 \mathrm{Aa} \alpha$ & $3.55 \mathrm{Aa} \alpha$ & $3.55 \mathrm{Aa} \alpha$ & $3.55 \mathrm{Aa} \alpha$ \\
\hline $25 \%$ & $2.77 \mathrm{Ab} \beta$ & $4.52 \mathrm{Aa} \alpha$ & $4.79 \mathrm{Aa} \alpha$ & $2.66 \mathrm{Ab} \beta$ \\
\hline $50 \%$ & $4.20 \mathrm{Aa} \alpha$ & $2.81 \mathrm{Ba} \alpha$ & $1.65 \mathrm{Bb} \alpha$ & $2.82 \mathrm{Aa} \alpha$ \\
\hline $75 \%$ & $2.65 \mathrm{Aa} \alpha$ & $4.14 \mathrm{Aa} \alpha$ & $1.34 \mathrm{Ba} \alpha$ & $1.73 \mathrm{Ab} \alpha$ \\
\hline $100 \%$ & $2.72 \mathrm{Aa} \alpha$ & $2.04 \mathrm{Ba} \alpha$ & $1.52 \mathrm{Ba} \alpha$ & $2.06 \mathrm{Aa} \alpha$ \\
\hline
\end{tabular}

APL

\begin{tabular}{|c|c|c|c|c|}
\hline \multicolumn{5}{|c|}{ Genetic Material } \\
\hline \multirow{3}{*}{$\begin{array}{c}\text { Extract Concentra- } \\
\text { tions }\end{array}$} & \multicolumn{2}{|c|}{ E. grandis $\times$ E. urophylla } & \multicolumn{2}{|c|}{ E. grandis $\times$ E. camaldulensis } \\
\hline & \multicolumn{4}{|c|}{ Leaf } \\
\hline & Young & Mature & Young & Mature \\
\hline $0 \%$ & $2.31 \mathrm{Ba} \alpha$ & $2.31 \mathrm{Ba} \alpha$ & $2.31 \mathrm{Aa} \alpha$ & $2.31 \mathrm{Aa} \alpha$ \\
\hline $25 \%$ & $1.95 \mathrm{Ba} \beta$ & $3.45 \mathrm{Aa} \alpha$ & $2.67 \mathrm{Aa} \alpha$ & $2.36 \mathrm{Ab} \alpha$ \\
\hline $50 \%$ & $3.07 \mathrm{Aa} \alpha$ & $2.42 \mathrm{Ba} \alpha$ & $1.47 \mathrm{Bb} \alpha$ & $2.31 \mathrm{Aa} \alpha$ \\
\hline $75 \%$ & $1.82 \mathrm{Ba} \beta$ & $3.23 \mathrm{Aa} \alpha$ & $0.86 \mathrm{Bb} \alpha$ & $1.75 \mathrm{Ab} \alpha$ \\
\hline $100 \%$ & $2.68 \mathrm{Aa} \alpha$ & $2.26 \mathrm{Ba} \alpha$ & $1.47 \mathrm{Bb} \alpha$ & $2.35 \mathrm{Aa} \alpha$ \\
\hline \multicolumn{5}{|c|}{ F Values } \\
\hline & \multicolumn{2}{|c|}{ RL } & \multicolumn{2}{|c|}{ APL } \\
\hline GM & \multicolumn{2}{|c|}{$8.388^{* *}$} & \multicolumn{2}{|c|}{$16.476^{* *}$} \\
\hline LMS & \multicolumn{2}{|c|}{$0.202^{\mathrm{ns}}$} & \multicolumn{2}{|c|}{$8.771^{* *}$} \\
\hline EC & \multicolumn{2}{|c|}{$5.965^{* *}$} & \multicolumn{2}{|c|}{$2.595^{\star}$} \\
\hline $\begin{array}{c}\text { Interaction } \\
(\mathrm{GM} \times \mathrm{LMS} \times \mathrm{EC})\end{array}$ & \multicolumn{2}{|c|}{$4.774^{* *}$} & \multicolumn{2}{|c|}{$4.774^{\star *}$} \\
\hline CV (\%) & \multicolumn{2}{|c|}{38.32} & \multicolumn{2}{|c|}{27.38} \\
\hline
\end{tabular}

Means followed by the same capital letter in the column [extract concentrations (EC)], lowercase in the line [different genetic material (GM)] and even maturation stage of leaf (EMF)) and averages followed by the same Greek letter in the line [different Leaf maturation stages (LMS) and the same genetic material)] do not differ from each other by the Scott-Knott test at $5 \%$ level. ${ }^{*}$ Significant at $1 \%$ of probability by the $\mathrm{F}$ test, ${ }^{*}$ Significant at $5 \%$ of probability by the $\mathrm{F}$ test and ${ }^{\mathrm{n}} \mathrm{Not}$ significant.

It was verified that the increase of the concentrations did not negatively affect the growth of the seedlings aerial part length, unlike other variables (Table 2), and larger values were verified in some treatments, when compared to the control treatment. Contrary results were presented by [19] for Lactuca sativa L., 
when found relationship inversely proportional with the increased concentrations of the tested extracts.

In accordance with [5], the initial seedlings growth is more affected by the aqueous extracts than the germination. For [20], allelopathic substances can either promote or inhibit the initial plant growth, which would explain the distinct responses on the root and aerial part growth of millet seedlings.

The chemical compounds responsible for the allelopathy phenomenon can be found in distinct parts of the plants and distributed into them under different concentrations during their life cycle [21]. Generally, allelochemicals have selective actions, just as plants may also have selectivity in their responses [22]. Such information confirms the observations of this study, when analyzing under isolated way the factor of maturation stages of the leaves, in which, the young leaves were responsible for promoting greater inhibition of the aerial part growth of the millet seedlings.

As for germination percentage and germination speed index, the extracts concentrations from $25 \%$ also affected negatively the mean values of dry mass of the root system and aerial part of the millet seedlings (Table 3).

The allelopathic effect presented by the two used genetic materials may be related to one of their components (Eucalytus urophylla and Eucalytus grandis), because allochemical substances have been found in the E. urophylla [23] and $E$. grandis [7] species.

In general, results indicate allelopathic potential of the studied genetic materials, since the substances present in the extracts could reduce the percentage of seed germination and the millet seedlings performance. The present study and other works related to allelopathy among species also show inhibitory effects of aqueous extracts of Pinustaeda [24]; Joanesia princeps Vell., and Casearia sylvestris Sw. [25]; Eucalyptus urophylla S. T. Blake [23]; Eucalyptus grandis Hill ex Maiden [7]; Eucalyptus urograndis [18]; Avenastrigosa Schreb. and Loliummultiflorium Lam. [21].

Considering the above mentioned, the effects of leaf extracts of the two Eucalyptus genetic materials observed in this study on the germination and initial development of millet seedlings are important aspects in areas of Agroforestry Systems (AFSs) implantation using these genetic materials in consortium with millet, because the substances resulting from their leaves decomposition can affect the germination performance of millet seeds and favor the seedling emergence imbalance and consequent harvesting imbalance, fact that may lead to losses on the crop quality and productivity. However, [1] emphasized the importance to consider that, under field conditions, the actions of the allelochemical compounds may be different from those observed in vitro. In this sense, [2] and [3] stated that many processes used to identify certain extracts that have allelopathic effects do not allow to conclude under which field conditions such effects will be shown, only prove the existence of allelochemicals in the plant material. 
Table 3. Mean values of dry mass of the root system (DMR) and aerial part (DMAP) of seedlings ( $\mathrm{mg}$ plantula ${ }^{-1}$ ) of millet submitted to the action of extract different concentrations of young and mature leaves of different genetic materials of eucalyptus.

\begin{tabular}{|c|c|c|c|c|}
\hline \multicolumn{5}{|c|}{ DMR } \\
\hline \multicolumn{5}{|c|}{ Genetic Material } \\
\hline \multirow{3}{*}{$\begin{array}{c}\text { Extract } \\
\text { Concentrations }\end{array}$} & \multicolumn{2}{|c|}{ E. grandis $\times$ E. urophylla } & \multicolumn{2}{|c|}{ E. grandis $\times$ E. camaldulensis } \\
\hline & \multicolumn{4}{|c|}{ Leaf } \\
\hline & Young & Mature & Young & Mature \\
\hline $0 \%$ & $3.81 \mathrm{Aa} \alpha$ & 3.81 Aa $\alpha$ & $3.81 \mathrm{Aa} \alpha$ & $3.81 \mathrm{Aa} \alpha$ \\
\hline $25 \%$ & $2.23 \mathrm{Bb} \beta$ & $2.73 \mathrm{Ba} \alpha$ & $3.17 \mathrm{Ba} \alpha$ & $2.17 \mathrm{Bb} \beta$ \\
\hline $50 \%$ & $2.55 \mathrm{Ba} \beta$ & $3.00 \mathrm{Ba} \alpha$ & $2.44 \mathrm{Ca} \alpha$ & $2.49 \mathrm{Bb} \alpha$ \\
\hline $75 \%$ & $1.93 \mathrm{Ba} \alpha$ & $2.30 \mathrm{Ca} \alpha$ & $2.09 \mathrm{Da} \alpha$ & $1.60 \mathrm{Cb} \beta$ \\
\hline $100 \%$ & $2.32 \mathrm{Ba} \alpha$ & $2.35 \mathrm{Ca} \alpha$ & $1.87 \mathrm{Db} \alpha$ & $1.16 \mathrm{Db} \beta$ \\
\hline
\end{tabular}

Genetic Material

\begin{tabular}{|c|c|c|c|c|}
\hline \multirow{3}{*}{$\begin{array}{c}\text { Extract Concentra- } \\
\text { tions }\end{array}$} & \multicolumn{2}{|c|}{ E. grandis $\times$ E. urophylla } & \multicolumn{2}{|c|}{ E. grandis $\times$ E. camaldulensis } \\
\hline & \multicolumn{4}{|c|}{ Leaf } \\
\hline & Young & Mature & Young & Mature \\
\hline $0 \%$ & $2.97 \mathrm{Aa} \alpha$ & 2.97 Аа $\alpha$ & $2.97 \mathrm{Aa} \alpha$ & $2.97 \mathrm{Aa} \alpha$ \\
\hline $25 \%$ & $1.71 \mathrm{Bb} \beta$ & $2.16 \mathrm{Ba} \alpha$ & $2.57 \mathrm{Ba} \alpha$ & $1.62 \mathrm{Bb} \beta$ \\
\hline $50 \%$ & $1.87 \mathrm{Ba} \beta$ & $2.30 \mathrm{Ba} \alpha$ & $2.00 \mathrm{Ca} \alpha$ & $1.79 \mathrm{Bb} \alpha$ \\
\hline $75 \%$ & $1.08 \mathrm{Cb} \beta$ & $2.30 \mathrm{Ba} \alpha$ & $1.65 \mathrm{Da} \alpha$ & $0.94 \mathrm{Cb} \beta$ \\
\hline $100 \%$ & $1.74 \mathrm{Ba} \alpha$ & $1.75 \mathrm{Ca} \alpha$ & $1.30 \mathrm{~Eb} \alpha$ & $1.07 \mathrm{Cb} \alpha$ \\
\hline \multicolumn{5}{|c|}{ F Values } \\
\hline & \multicolumn{2}{|c|}{ DMR } & \multicolumn{2}{|c|}{ DMAP } \\
\hline GM & \multicolumn{2}{|c|}{$12.950^{\star *}$} & \multicolumn{2}{|c|}{$15.343^{* *}$} \\
\hline LMS & \multicolumn{2}{|c|}{$1.445^{\mathrm{ns}}$} & \multicolumn{2}{|c|}{$0.004^{\mathrm{ns}}$} \\
\hline EC & \multicolumn{2}{|c|}{$102.388^{\star *}$} & \multicolumn{2}{|c|}{$117.444^{* *}$} \\
\hline $\begin{array}{c}\text { Interaction } \\
(\mathrm{GM} \times \mathrm{LMS} \times \mathrm{EC})\end{array}$ & \multicolumn{2}{|c|}{$3.487^{*}$} & \multicolumn{2}{|c|}{$12.802^{\star *}$} \\
\hline CV (\%) & \multicolumn{2}{|c|}{11.60} & \multicolumn{2}{|c|}{11.31} \\
\hline
\end{tabular}

Means followed by the same capital letter in the column [extract concentrations (CE)], lowercase in the line (different genetic material (GM) and the same leaf maturation stage (LMS)] and means followed by the same Greek letter in the line [different leaf maturation stages (LMS) and the same genetic material] do not differ from each other by the Scott-Knott test at $5 \%$ level. ${ }^{*}$ Significant at $1 \%$ and ${ }^{*}$ at $5 \%$ of probability by the $\mathrm{F}$ test

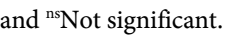

\section{Conclusion}

The aqueous extracts of young and mature leaves of the tested genetic material present allelopathic potential on the millet seedlings, because they interfered in the germination and in its initial growth, and the $\mathrm{pH}$ is disconnected from possible interferences. 


\section{Acknowledgements}

The authors thank Eco Empreendimentos Ambiental Ltda. for the supply of genetic material and by the Federal University of Piauí/Campus Professora Cinobelina Elvas for the research support.

\section{References}

[1] Yamagushi, M.Q., Gusman, G.S. and Vestena, S. (2011) Allelopathic Effect of Aqueous Extracts of Eucalyptus globules Labill. and of Casearia sylvestris Sw. on Crops. Semina: CiênciasAgrárias, 32, 1361-1374.

http://www.uel.br/revistas/uel/index.php/semagrarias/article/view/5080/8900 https://doi.org/10.5433/1679-0359.2011v32n4p1361

[2] Corsato, J.M., Fortes, A.M.T., Santorum, M. and Leszczynski, R. (2010) Allelopathic Effect of Sunflower Water Extract on the Germination of Soybean and Hairy Beggartick. Semina: Ciências Agrárias, 31, 353-360.

http://www.uel.br/revistas/uel/index.php/semagrarias/article/view/5306/4828 https://doi.org/10.5433/1679-0359.2010v31n2p353

[3] Taiz, L. and Zeiger, E. (2013) Plant Physiology. 5th Edition, Artmed, Porto Alegre.

[4] Wandscheer, A.C.D. and Pastorini, L.H. (2008) Allelopathic Interference of Raphanus raphanistrum L. on the Germination of Lactuca sativa L. and Solanum lycopersicon L. Ciência Rural, 38, 949-953.

http://www.scielo.br/pdf/cr/v38n4/a07v38n4.pdf https://doi.org/10.1590/S0103-84782008000400007

[5] Ferreira, A.G. and Aquila, M.E. (2000) Alellopathy: An Emerging Topic in Ecophysiology. Revista Brasileira de Fisiologia Vegetal, 12, 175-204.

http://www2.esalq.usp.br/departamentos/lpv/lpv672/semana\%204/11\%20-\%20Refer encia\%20para\%20leitura\%20-\%20\%20Alelopatia\%20na\%20agricultura.pdf

[6] Priesnitz, R., da Costa, A.C.T., Jandrey, P.E., Fréz, J.R. da S., Duarte Júnior, J.B. and de Oliveira, P.S.R. (2011) Space between the Lines in the Productivity of Biomass and Grains in Genotypes of Pearl Millet. Semina: CiênciasAgrárias, 32, 485-494. http://www.uel.br/revistas/uel/index.php/semagrarias/article/view/3394/8408

[7] Souza, V.M. and Cardoso, S.B. (2013) Allelopathic Effect of Eucalyptus grandis Leaves Extracton the Germination of Lactuca sativa L. (lettuce) and Phaseolus vulgaris L. (bean). Revista Eletrônica de Educação e Ciência, 3, 1-6.

http://fira.edu.br/revista/vol3_num2_pag1.pdf

[8] Haida, K.S., Coelho, S.R.M., Haas-Costa, J., Viecelli, C.A., Alekcevetch, J.C. and Barth, E.F. (2010) Allelopathic Effect of Achillea millefolium L. about Lactuca sativa L. Seeds. Revista em Agronegócio e Meio Ambiente, 3, 101-109. http://periodicos.unicesumar.edu.br/index.php/rama/article/view/1088/1021

[9] Ferraz, A.P.F., Pinto, M.A.D.S.C., Coelho Júnior, L.F., Calado, T.B. and Araújo, A.V. (2014) Allelopathic Potential of Aqueous Extract of Eucalyptus Leaves on Germination and Early Growth of Onion and Tomato. Enciclopédia Biosfera, 10, 1493-1506.

http://www.conhecer.org.br/enciclop/2014b/AGRARIAS/potencial\%20alelopatico.p df

[10] Gusman, G.S., Bittencourt, A.H.C. and Vestena, S. (2008) Allelopathy of Baccharis dracunculifolia DC. on the Germination and Development of Cultivated Species. Revista Acta Scientiarum Biological Sciences, 30, 119-125.

http://periodicos.uem.br/ojs/index.php/ActaSciBiolSci/article/view/3592/2530 
[11] BRASIL (Ministério da Agricultura, Pecuária e Abastecimento) (2009) SeedAnalysis Rules. Ministério da Agricultura, Pecuária e Abastecimento, Secretaria de Defesa Agropecuária, Brasília.

http://www.agricultura.gov.br/assuntos/insumos-agropecuarios/arquivos-publicaco es-insumos/2946regrasanalisesementes.pdf

[12] Maguire, J.D. (1962) Speed of Germination-Aid in Selection and Evaluation for Seedling Emergence and Vigor. Crop Science, 2, 176-177.

https://dl.sciencesocieties.org/publications/cs/abstracts/2/2/CS0020020176/ https://doi.org/10.2135/cropsci1962.0011183X000200020033x

[13] Nakagawa, J. (1999) Seedlings Performance Based Vigor Test. In: Krzyzanowki, F.C., Vieira, R.D. and França Neto, J.B., Eds., Vigor de sementes: Conceitos e testes, ABRATES, Londrina, 1-21.

[14] Ferreira, D.F. (2011) Sisvar: A Computer Statistical Analysis System. Ciência e Agrotecnologia, 35, 1039-1042. https://doi.org/10.1590/S1413-70542011000600001

[15] Eberlein, C.V. (1987) Germination of Sorghum almum Seeds and Longevity in Soil. Weed Science Lawrence, 35, 796-801.

https://www.cambridge.org/core/journals/weed-science/article/germination-of-sorg hum-almum-seeds-and-longevity-in-soil/BADD519040A4D5A09A6CBF756BEEF8 61

[16] Moraes, P.V. and Agostinetto, D. (2009) Allelopathy Weeds Inhibition Species of Cover in Corn Cropping. Revista Brasileira de Agroecologia, 4, 117. http://aba-agroecologia.org.br/revistas/index.php/rbagroecologia/article/view/9778/ $\underline{6611}$

[17] Ribeiro, J.P.N., Matsumoto, R.S., Takao, L.K., Voltarelli, V.M. and Lima, M.I.S. (2009) Allelopathic Effects of Aqueous Extracts of Crinum americanum L. Revista Brasileira de Botânica, 32, 183-188.

http://www.scielo.br/pdf/rbb/v32n1/a18v32n1.pdf https://doi.org/10.1590/S0100-84042009000100018

[18] Carvalho, F.P., Melo, C.A.D., Machado, M.S., Dias, D.C.F.S. and Alvarenga, E.M. (2015) The Allelopathic Effect of Eucalyptus Leaf Extract on Grass Forage Seed. Planta Daninha, 33, 193-201. https://doi.org/10.1590/0100-83582015000200004

[19] Silveira, P.F., Maia, S.S.S. and Coelho, M.D.F.B. (2012) Allelopathy Potential of Mimosa tenuiflora (Willd.) Poir. Aqueous Leaf Extract of Lactuca sativa L. Germination. Bioscience Journal, 28, 472-477.

http://www.seer.ufu.br/index.php/biosciencejournal/article/view/12409/9592

[20] Sobrero, M.T., Ochoa, M.D.C. and Chaila, S. (2004) Allelopathic Potencial of Wedelia glauca: Effects on Horticultural Species. Planta Daninha, 22, 71-75.

http://www.scielo.br/pdf/pd/v22n1/20147.pdf https://doi.org/10.1590/S0100-83582004000100009

[21] Cavalli, M., da Silva Santos, M., Barros, M.K.L.V., Barros, H.M.M. and Barosi, K.X.L. (2016) Allelopathic Potential of the Aqueous Extract of Black Oats and Ryegrass in the Germination and Initial Growth of the Sudan Grass. Revista Verde de Agroecologia e Desenvolvimento Sustentável, 11, 70-76.

http://www.gvaa.com.br/revista/index.php/RVADS/article/view/4675/4066

[22] Oliveira, L.G.A., Belinelo, V.J., Almeida, M., Aguilar, E. and Vieira Filho, S.A. (2011) Allelopathy of Emilia sonchifolia (L.) Dc. (Asteraceae) on the Germination and Early Growth of Sorghum, Cucumber and Black Dick. Enciclopédia Biosfera, 7, 1-10. http://www.conhecer.org.br/enciclop/2011a/agrarias/Alelopatia.pdf 
[23] Albach, A.C.C., Almeida, V.P., Breier, T.B. and Barrella, W. (2010) Allelopathic Potential of Eucalyptus orophila Leaves. Revista Eletrônica de Biologia, 3, 32-47. https://revistas.pucsp.br/index.php/reb/article/view/59/3316

[24] Sartor, L.R., Adami, P.F., Chini, N., Martin, T.N., Marchese, J.A. and Soares, A.B. (2009) Allelopathic of Pinus taeda Needles on the Germination and Development of Avena strigosa Seedlings. Ciência Rural, 39, 1653-1659. http://www.scielo.br/pdf/cr/v39n6/a232cr973.pdf

[25] Capobiango, R.A., Vestena, S. and Bittencourt, A.H.C. (2009) Allelopathy of Joanesia princeps Vell. and Casearia sylvestris Sw. on the Cultivated Species. Revista Brasileira de Farmacognosia, 19, 924-930.

http://www.scielo.br/pdf/rbfar/v19n4/23.pdf 